\title{
Fritz Müller's legacy on Axel Heiberg Island, Nunavut, Canada
}

\author{
Peter Adams \\ Trent University, Peterborough, Ontario K97 7B8, Canada
}

\begin{abstract}
Fritz Müller (1926-80) was the leader of the Jacobsen-McGill Arctic Research Expeditions to Axel Heiberg Island, Nunavut, Canada. He was a faculty member at McGill University, Montréal, Canada, from 1959 to 1970. Thereafter, he was Chair of Geography at Eidgenössische Technische Hochschule, Zürich, Switzerland. He conducted research on Axel Heiberg Island, mainly in the vicinity of Expedition Fiord, from 1959 until his death in 1980. This paper is a personal account of Müller's work by one of his students, with a commentary on his contributions to Arctic science. The personal account focuses on the early years of the expeditions. The commentary includes discussion of glacier mass-balance records and lake-ice break-up from 1959 to the present, glacier-terminus records from 1948 to the present and other research focused on the region.
\end{abstract}

\section{INTRODUGTION}

Fritz Müller (1926-1980) (Fig. 1), a graduate of the University of Zürich, Switzerland, was a Carnegie Arctic Scholar at McGill University, Montréal, Canada, in the mid-1950s. In 1959, he returned to Canada as leader of the JacobsenMcGill Arctic Research Expedition to Axel Heiberg Island, in what is now Nunavut Territory. He worked at McGill until 1970, when he returned to Zürich as head of the Department of Geography at Eidgenössische Technische Hochschule (ETH). Until his death on Rhonegletscher in 1980, he retained honorary status and an office at McGill and so was able to maintain his research in high-Arctic Canada from bases in both Switzerland and Montréal. While his doctoral work was on pingos in the Mackenzie Delta, he is best known for his glacier studies on Axel Heiberg Island and for the North Water Project, a study of the relatively ice-free area between Devon and Ellesmere Islands and Greenland. At McGill, he was the prime mover of an interdisciplinary graduate program in glaciology.

We outlined Fritz's career in his obituary (Adams and Ommanney, 1981). After his death, his wife Barbara and two daughters, Barbara and Hanna, returned to Canada. The elder Barbara died in Toronto.

This paper was written for the session of the International Symposium on the Verification of Cryospheric Models named in Fritz's honour by the International Glaciological Society (IGS). The symposium was held at ETH. As is appropriate for such a conference, the focus was Fritz's work on the glaciers of Axel Heiberg Island, rather than the North Water. However, it should be noted that during the period 1996-99 a major international project was undertaken on the North Water, building on Fritz's work. I begin with a personal memoir and conclude with a commentary on his research. The perspective is a 40 year one from the start of the work on Axel Heiberg Island to 20 years after the date of Fritz's death.

*Contribution to the Fritz Müller Memorial, Zürich, 1999.

\section{PERSONAL MEMORIES}

I first heard of Fritz Müller, although not by name, in early summer 1959. In my student residence in Britain, I received a cable from McGill University offering me a scholarship and

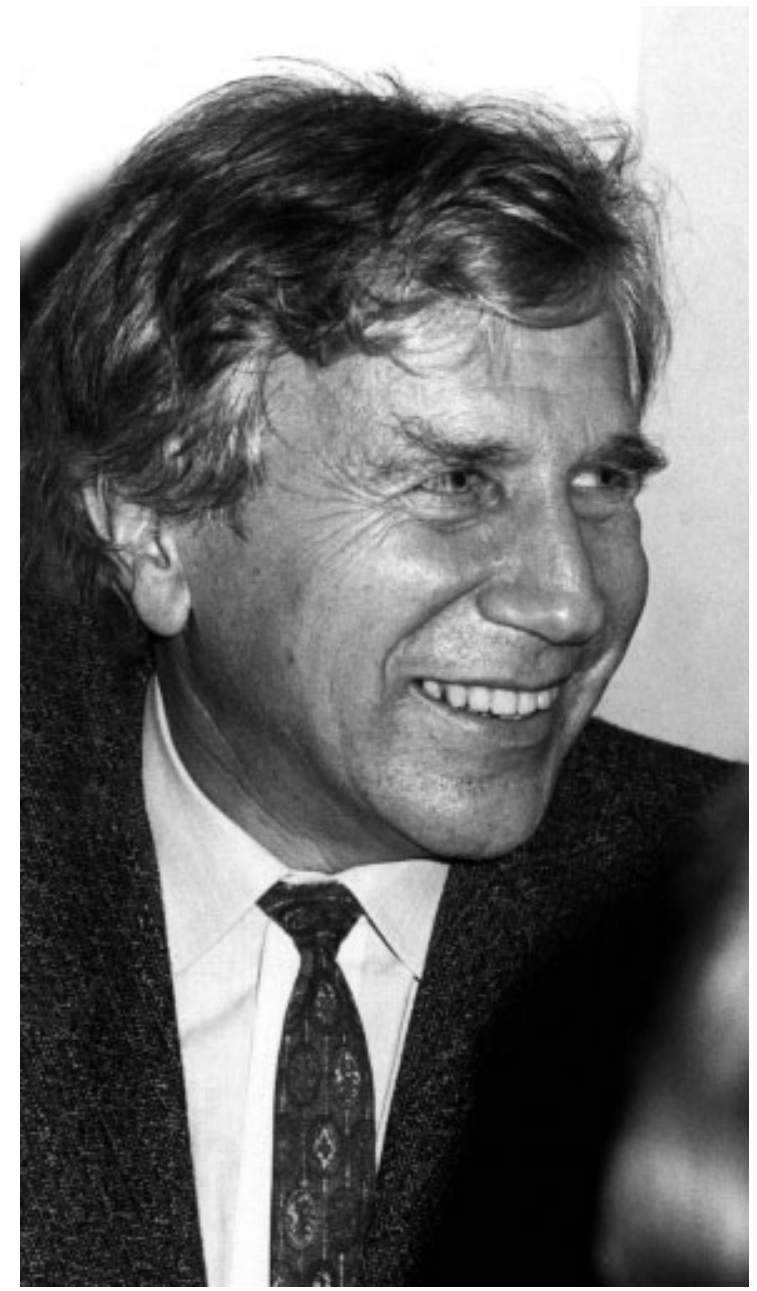

Fig. 1. Fritz Müller (photo by K. Steffen). 


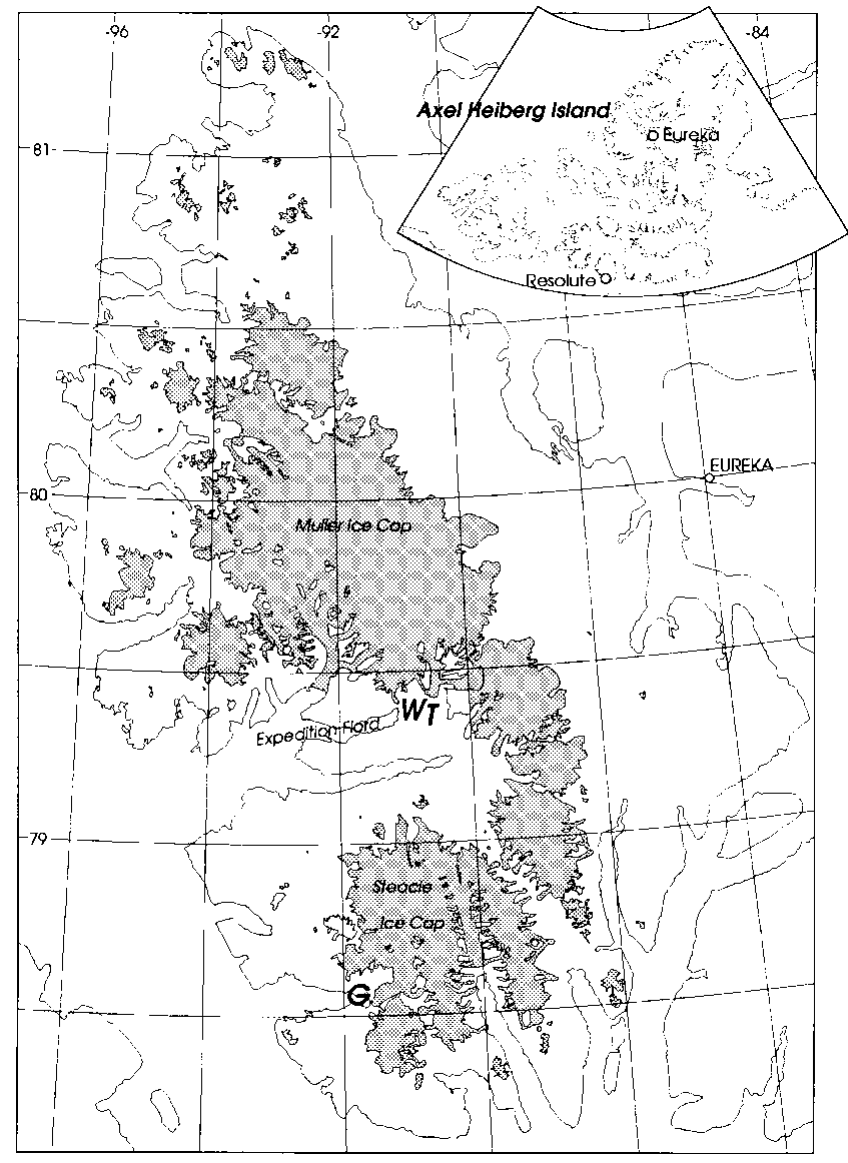

Fig. 2. Axel Heiberg Island, Nunavut, Canada. W, White Glacier; T, Thompson Glacier; G. Good Friday Bay Glacier. Good Friday Bay Glacier was the subject of Müller (1969b); its unusual advance during the 1950s and 1960s appears to have been an example of "near-surge-like" behaviour.

"the position of assistant to the Leader of the Arctic Islands Expedition". Two or three weeks later, I met this leader, Fritz, in Montréal. After a couple of days there, we went to Churchill and then slowly on to Resolute and the west coast of Axel Heiberg Island, in the then Northwest Territories, now Nunavut Territory, Canada (Fig. 2). We were looking for a site suitable for "long-term, in-depth, interdisciplinary study of a high arctic region". I was not aware of the context of this activity at the time, but the project was a fairly natural outcome of northern research at McGill in the 1950s (Adams, 1998). Completion of the vertical aerial photography of the northern Arctic islands had made such a project feasible. I suspect that Axel Heiberg Island had become the focus of interest because George Jacobsen, the businessman who funded the early work, had landed on Buchanan Lake, in eastern Axel Heiberg Island, in the early 1950s and because of Fritz's interest in glaciers rather than other phenomena amenable to interdisciplinary study.

We briefly visited various sites on western Axel but soon arrived in what is now known as Expedition Fiord. "We" were Haaken Kranck, a retired geology professor who had a special interest in anhydrite-gypsum diapirs (of which there are some in Expedition Fiord), George Jacobsen, Fritz and myself. Our pilot was W.W. (Weldy) Phipps, flying a Piper Super Cub equipped with then experimental large, low-pressure tires. I now believe that Fritz had picked the site of the future expedition from aerial photos, before we left, mainly on the basis of the range of easily accessible glaciers. Be that as it may, Kranck and Jacobsen left soon after we arrived in Expedition Fiord and Phipps, whose skills were a key underpinning of this and future years' work on and off the glaciers, flew off to other clients, dropping in from time to time to check on us. After that, Fritz was the leader and I was the expedition. As far as I can recall we did not have a radio.

I think that Fritz was surprised that I could neither ski nor cook. These were natural attributes for a Swiss who had spent three seasons with Lauge Koch expeditions in Greenland, two field seasons in the Mackenzie Delta, and who had climbed to $8000 \mathrm{~m}$ on Everest (followed by a field season on Khumbu Glacier), as well as having done innumerable field trips and Swiss army exercises in the Alps. He thought that I was faking about my lack of cooking until I followed a ricepacket recipe for a curry which called for various types of pepper and, not being familiar with green and red peppers, I put a slug of black pepper in whenever pepper was called for. Being hungry, we both ate rapidly, and spent the night with a pail of ice water between us in the two-man (as they were then called) tent. Fortunately, the main work of the "assistant to the leader", in addition to cooking, was carrying. That I was good at.

One of my main contributions to the Axel Heiberg Island expeditions was as a porter. It took Fritz some time to discover that his non-skiing assistant was an international distance runner coming off his best-ever cross-country season. I enjoyed carrying stuff, and that enjoyment and my association with Fritz Müller changed my life and led me to a most exciting and enjoyable career. When I received my Ph.D., someone said that the "D" stood for donkey and that the "Ph" was a fancy way of writing " $\mathrm{f}$ ". This delighted me then and it still does.

Once the expedition region had been selected, our main tasks were to begin the basic triangulation which would provide some control for our aerial photos as a basis for future years' work, and to initiate glacier mass-balance, movement and englacial-temperature studies on what became Crusoe, Baby and White Glaciers. We did this on foot, mainly from a camp in the delta of what is now known as Expedition River, near sea level. The surveying involved climbing a prominent peak, doing a full round of survey points identified from photos, building a cairn and then descending to camp to sleep before tackling the next peak. My jobs were to carry the theodolite stand (Fritz never trusted me with the theodolite itself), other gear and food, to keep the fieldbook, and carry rocks to the top of the mountain for the magnificent cairns which Fritz built. I forgot to mention that I had also never taken Cairn Building 101 which was apparently compulsory at the University of Zürich. As there were only two of us, it was virtually impossible to carry tents and sleeping-bags on these trips, so the work usually involved more than 24 hours of travel, but the light and weather were always good. Generally we travelled on rock, sometimes on mixed ice and rock.

We operated in this same fashion for the Crusoe and Baby Glacier work, carrying bamboo stakes and a hand drill with extensions, as well as the theodolite. However, for White Glacier, which became the focus of Fritz's own research and of much of future expeditions' activities, we had to relay equipment from the delta to establish a fly camp on the glacier's outwash plain. From this camp, we carried on to Moraine Camp ( $\sim 850 \mathrm{~m}$ a.s.l.) where we worked in what we now know is the equilibrium zone. On the snout of the glacier, our hand drilling included a $10 \mathrm{~m}$ temperature hole. We used crampons and rope for this work; fortunately 
skis were not necessary (although we carried them). I later realized that had he not accommodated my lack of skiing skills, Fritz could have skied down, with a load, over the bare ice. This would have taken him minutes rather than the hours which each trip required without skis.

It was $24+$ hour activity like this which made it possible for us to eat peppered curry without noticing.

Returning after many days' absence on White Glacier, we discovered that our delta camp had been destroyed by a pair of wolves. They had shredded the heavy kitchen tent, chewed flat and punctured most of our canned supplies and urinated in sacks of flour. We had left the rifle and the small tent at White Glacier (I was carrying enough), but Fritz assured me that the wolves were harmless; apparently wolves had followed him on a previous trip for several days while crossing Peary Land, northern Greenland. We built a shelter from sod and drums, crawled in, covered up the entrance and slept. The wolves watched us with interest. We did not see them again that year.

During our carrying trips between the delta and White Glacier, we passed by what is now called Colour Lake which Fritz decided should become the site for the expedition base houses due to be built in 1960. This site was within walking distance of key glaciers, it had fresh water, was beside a gypsum diapir and close to the sulphur springs which are one of the features of interest of the region. My last task that summer was carrying gear to a cache near the lake to be ready for the following season. Weldy Phipps (and Dick Deblicky) picked us up there, landing on the rough ground which became the expedition airstrip when the lake ice cover would not support aircraft.

I spent the four summer months of 1960 and 1961 on Axel Heiberg Island working on the glaciers, especially Baby and White. There were around 20 of us in each of those years, so I saw much less of Fritz even though he had become my thesis supervisor. I was the first student in his glaciology program at McGill. He operated out of the Colour Lake base camp, from his tent which was located close to the two houses which are still in use today. He kept a keen eye on all aspects of the expeditions' work, driving in particular the mapping program which produced the best topographic and geological maps of the Canadian High Arctic. In retrospect, the entire operation in those and following years was an extension of Fritz's mind.

In some ways, he was very much in the "expedition" tradition. We were explorers, mapping and naming new territory. He kept a detailed journal (I have never seen it) in addition to meticulous field notes. He kept control of the booze, doling it out on what he considered special occasions. He was keen, to a fault, on the expeditions' report series (which is itself a remarkable memorial to him), at the expense of journal publication.

In other ways, he was at the leading edge of modern polar research projects. There was an overall design to all our work, based on Fritz's own thoughts and on ideas developing at McGill, especially those of Ken Hare, who as Chair of Geography and Dean, spearheaded this and other field research projects in the 1950s and 1960s. The view was that the time was ripe for long-term, intensive, inter- and multidisciplinary studies of high-Arctic Canada, rather than the more extensive, short-term expedition-type projects which had necessarily dominated until then. Fritz also thought of his expeditions as an extension of the university into the field. This, again, was giving structure to thought about Arctic studies at McGill in the 1950s (see Adams, 1998). I am not sufficiently familiar with the Lauge Koch expeditions of the 1940s and 1950s to be able to say how much of Fritz's approach to such matters was influenced by his experience with them.

It is remarkable how many seeds planted by Fritz in 1959 have borne fruit. It is even more remarkable how work in 1960 and 1961, the foundation years of the expeditions, has continued to steer research on Axel Heiberg Island until today.

Although my wife Jill spent two full summers living with Barbara Müller and her first baby (a great kindness on Barbara's part); although Fritz and Barb were good godparents to one of our daughters; although I worked alongside Fritz in the expedition office at McGill; and although he was my supervisor, I never got closer to him than in that summer of 1959. Only then did I learn a little about the more personal side of his life: travelling by Greyhound bus most of the way to the Mackenzie Delta for his pingo research, training Buddhist monks to read thermometers on the Khumbu and his sneak visit to Tibet, losing a packsack with a season's data in a stream in Greenland, and so on. It was then also that I learned a little about his childhood in a Swiss village (it was his goddaughter who told me just how isolated his home was) and about his experience in the Swiss army (I thought that all Swiss loved military service until I met a Swiss who had not been an officer). He was hooked, as was I, on the expedition thing, on the romance of it and the need to do things the hard way. He named Baby Glacier after his first daughter, although places in Canada cannot be named after living people. He gave Crusoe Glacier that name because we lived for a while below it in our homemade shelter. He loved naming places and features. You get glimpses of this sort of thing in parts of the coffee-table book he produced, The living Arctic (Müller, 1981). He would be very pleased that the ice cap is now named after him.

I soon discovered that he worked in Montréal with the same energy and intensity as we had worked on Axel Heiberg Island. He slept about 4 hours a night, year-round! I used to jog down to the bus with him, on his way home at night, to discuss my thesis.

In 1963, I went for 3 years to the McGill Subarctic Research Laboratory at Schefferville, a fly-in mining town in northern Quebec. This shifted my research focus from glaciers to lake ice (more hand-drilling) and snowpack. Then I went to Trent University in Peterborough, Ontario. One day in the 1970s, on a visit to McGill, I looked up from my breakfast in the Montréal YMCA restaurant to see Fritz nearby, eating, reading and making notes in a fieldbook. He had come from meetings in Washington, DC, for meetings and a lecture at McGill. He was going to Boston that night for more meetings before flying back to Zürich for a regular lecture at ETH. I had not seen him for years. During our chat I got a glimpse of the transatlantic web of projects that he was engaged in. Having had some experience of university administration by then, I was glad that I was not the dean who had to keep track of this stunning array of activities.

I know a five-star workaholic when I see one, as I am fairly highly rated myself.

When Fritz died so tragically young in 1980, I was asked to return to Axel Heiberg Island after an absence of almost 20 years. My job was to pick up the threads of his work and sort of set the stage for future work. I did this gladly, and my own university, Trent, working with McGill, which still runs the Axel Heiberg station, has retained an interest in this 
research ever since. We rediscovered Fritz's sites; we did our best to tabulate 20 years of data and work. Over the next few years, we refurbished the base houses and shipped out redundant equipment and material. The resulting publication includes a register of field parties which had worked in the region, and a bibliography of their work from 1959 until Fritz's death (Ommanney 1987a, b). My own renewed interest in the glaciers and Colour Lake continues to this day.

I was struck, as you will be, by the number and diversity of projects which had been undertaken since 1959. I was also struck by Fritz's sheer persistence with certain themes, especially with respect to White Glacier which has to be one of the most studied in the world. In the intervening years, power drills, snowmobiles and even all-terrain vehicles had become common. As a result, almost everyone could work out of the base camp. I slept in one of the base houses for the first time.

Today, 40 years after Fritz's first visit, his field station and the region he chose and mapped continue to attract researchers and students from all over Canada and abroad. McGill has recently received federal funding to help maintain the station. The variety of interests involved is greater now than in Fritz's day. The students who use it today can generally ski, bake various types of bread and brew beer, but they have a fatal attraction to power equipment and base-camp life. There is no great single driving force behind the work now, no one who takes an interest in each and every project in the region no matter what the academic discipline involved. But this is as it should be. The personal energy and focus which were necessary to set the stage and get things going would by now have begun to stifle.

Barbara Müller, who edited early Axel Heiberg Island reports, was a remarkable woman. Her first husband, Ben Battle, also died on a glacier. She and Ben had been part of the very exciting post-World War II era at Cambridge. She was a highly intelligent, articulate, compassionate woman who was somewhat older than Fritz and who had her children relatively late in life. While Fritz had an enormous influence on my academic and professional life, Fritz and Barbara together, mainly Barb, had a similar influence on our personal life. Jill and I remember Barbara and the children in Montréal, Zürich and Toronto. We and her goddaughter, our daughter Joanne, miss her.

\section{FRITZ MÜLLER'S RESEARGH LEGAGY ON AXEL HEIBERG ISLAND}

If you read Preliminary report 1961-62 (Müller and others, 1963), you get a good sense of what Fritz was about on Axel Heiberg. This was the second of the "preliminary reports" in the Axel Heiberg series (see Table 1). By the time it was published, the peak foundation years of the expeditions were already in the past, but their original concept was still fresh.

Yet, from the perspective of 1999, the most striking thing about this report is the focus on glaciers. Fewer than 40 of 241 pages deal with topics (e.g. geomagnetism, geology, mycology, the sulphur springs, faunal notes and permafrost) which do not directly involve the glaciers, and for several of them indirect relevance to glacier work is clearly apparent. All the other articles, in geophysics, meteorology, geomorphology, botany and mapping sections, as well as the glaciology section, involve work which adds to the understanding of the glaciers of the region. The articles in
Table 1. The Axel Heiberg Island Research Reports, McGill

University, Montréal, Quebec, H3A 2T5, Canada

LIST OF AXEL HEIBERG ISLAND RESEARCH REPORTS

In order of publication

Müller, B. S., ed. 1961. Jacobsen-McGill Arctic Research Expedition to Axel Heiberg Island, Queen Elizabeth Islands: preliminary report of 1959-1960. 219 pp.

Fricker, P. E. 1963. Geology of the Expedition area, western central Axel Heiberg Island, Canadian Arctic Archipelago. Geology 1. 156 pp.

Fricker, P. E. and H. P. Trettin. 1963. Pre-Mississippian succession of northernmost Axel Heiberg Island, Canadian Arctic Archipelago. Geology 3. 27 pp.

Müller, F. and 18 others. 1963. Jacobsen-McGill Arctic Research Expedition 1959 1962; preliminary report 1961-1962 and map supplement. 241 pp. +6 maps

Andrews, R. H. G. 1964. Meteorology and heat balance of the ablation area, White Glacier, Canadian Arctic Archipelago - summer 1960 (Lower Ice Station: $79^{\circ} 26^{\prime} \mathcal{N}, 90^{\circ} 39^{\prime} \mathrm{W}, 208 \mathrm{~m}$.). Meteorology $1.107 \mathrm{pp}$.

Havens, J. M. 1964. Meteorology and heat balance of the accumulation area, McGill Ice Cap, Canadian Arctic Archipelago - summer 1960 (Upper Ice Station I, $79^{\circ} 41^{\prime} \mathcal{N}, 90^{\circ} 27^{\prime} \mathrm{W}, 1530 \mathrm{~m}$ ). Meteorology $2.87 \mathrm{pp}$.

Hoen, E.W. 1964. The anhydrite diapirs of central western Axel Heiberg Island. Geology 2. 102 pp.

Havens, J. M., F. Müller and G. C. Wilmot. 1965. Comparative meteorological survey and a short-term heat balance study of the White Glacier, Canadian Arctic Archipelago - summer 1962. Meteorology 4.68 pp.

Redpath, B. B. 1965. Seismic investigation of glaciers on Axel Heiberg Island, Canadian Arctic Archipelago. Geophysics 1. 26 pp.

Adams, W. P. 1966. Ablation and run-off on the White Glacier, Axel Heiberg Island, Canadian Arctic Archipelago. Glaciology 1.77 pp.

Müller, F. and N. Roskin-Sharlin. 1967. A high arctic climate study of Axel Heiberg Island, Canadian Arctic Archipelago — summer 1961. Part I. General meteorology. Meteorology 3. 82 pp.

Maag, H. 1969. Ice-dammed lakes and marginal glacial drainage on Axel Heiberg Island, Canadian Arctic Archipelago. 147 pp.

Ommanney, C. S. L. 1969. A study in glacier inventory: the ice masses of Axel Heiberg Island, Canadian Arctic Archipelago. Glaciology 3. 183 pp.

Kälin, M. 1971. The active push moraine of the Thompson Glacier, Axel Heiberg Island, Canadian Arctic Archipelago, Canada. Glaciology 4.68 pp.

Müller, F. and members of the Expedition. 1972. International Geographical Union Field Tour Ea 2, Arctic Archipelago I, 22nd International Geographical Congress. Miscellaneous Papers. 56 pp.

Iken, A. 1974. Velocity fluctuations of an Arctic valley glacier; a study of the White Glacier, Axel Heiberg Island, Canadian Arctic Archipelago. Glaciology 5. 115 pp.

Arnold, K. C. 1981. Ice ablation measured by stakes and terrestrial photogrammetry - a comparison on the lower part of the White Glacier: Axel Heiberg Island, Canadian Arctic Archipelago. Glaciology 2.98 pp.

Adams, P. 1987. Field research on Axel Heiberg Island, N.W.T., Canada: bibliographies and data reports with appendices of data from the McGill Subarctic Research Station, Schefferville, P.Q. Miscellaneous Papers 2. 207 pp.

Obtainable from the Department of Geography, McGill University, P.O. Box 6070, Station A, Montréal, Quebec H3A 2T5, Canada

Unpublished reports

Müller, F. 1964. Investigations in an ice shaft in the accumulation area of the McGill Ice Cap. Report for National Aeronautics and Space Administration. 17 pp.

Whiting, J. and F. Müller. 1969. Evaluation of the OTT automatic weather station. 87 pp.

Ohmura, A. 1970. Daily discharge of the Baby Glacier, 1969-70.

Scott, J. 1970. Evaluation of Plessey automatic weather station, summer 1970. $45 \mathrm{pp}$. 
the mapping section (Haumann, 1963a; Müller, 1963a) refer to the Map Supplement which contains 1:100 000, 1:50 000 and 1:5000 topographic maps and 1:63000 and 1:160000 geological sheets (see Fricker, 1963). It should be remembered that this is a part of the world where 1:250 000 maps are still the norm. Ommanney (1987a) includes a list of thematic maps which were produced using the Map Supplement maps as base. It is clear from papers written about the topographic maps (e.g. Blachut, 1963; Haumann, 1963b; Blachut and Müller, 1966) that, wonderful though they are as a representation of the landscape of the region, they were first and foremost glacier maps. Our mapping program was, in fact, a glacier-mapping program.

These maps, and various others based on them, are a key part of Fritz Müller's legacy. They have been invaluable to glaciologists and non-glaciologists. They, and the still-growing diverse data and literature base of the expeditions and years since, continue to attract students and researchers to Fritz's superbly located base.

Before turning to the glacier research, let me mention a selection of work which built on some of the summaries in this particular Preliminary report. These are examples of the way some of Fritz's seeds bore fruit.

Two "depth-sounding" projects are reported, one involving the sea portion of Expedition Fiord, the other Colour Lake (Müller, 1963a). Fritz's account of these makes it clear that his interest lay in the information which these water bodies provided on the past extent of the glaciers. This same interest was apparent in follow-up work during his time, on the lake sediments of Caflisch $(1970,1972)$. In more recent years, the work of Gilbert (1990) and Gilbert and others (1993) on marine sediments in Expedition Fiord has cast light on sedimentary processes there, including the possible effects of flood discharge from the ice-dammed lakes which were studied by Maag $(1969,1972)$ and others. Colour Lake, the source of water for base camp, proved to have a $\mathrm{pH}$ of 3.7, so tracking inputs from its relatively alkaline drainage basin is quite easy. It and its basin have proved to be a very productive site for various aspects of snowmelt and runoff and limnology (e.g. Allan and others, 1987; Adams and others, 1989; English and others, 1991; Schiff and others, 1991; Doran, 1993; Fishback, 1995; Doran and others, 1996, 1999). Figure 3 is an interesting example of the value of regular visits to a site by reasonably observant people. The apparent increase in frequency of two-summer ice covers in this record is even more pronounced than would at first appear, because of the negative feedback of the relative warmth of the water column in the second summer (Doran and others, 1996; Ecclestone and others, in press).

The account of the sulphur springs (Beschel 1963b) in the Preliminary report maintained interest in a feature which had been noted in 1959. The springs and their associated ice mounds continue to attract interest (e.g. Pollard, 1991a, b; Pollard and Van Everdingen, 1992). It has been speculated that there are links between Colour Lake and/or the very deep glacier-dammed Phantom Lake and/or subglacial recharge areas and the springs. NASA is interested in this matter, as microbial and mineralogical studies have exobiological (Mars) implications (see Andersen and others, 1998; Pollard and others, 1998, 1999; Omelon, 1999; personal communication from W. Pollard, 1999). Fritz would be pleased that thought has been given to use of the distinctive discharge of the springs to measure the runoff from White and Thompson Glaciers!

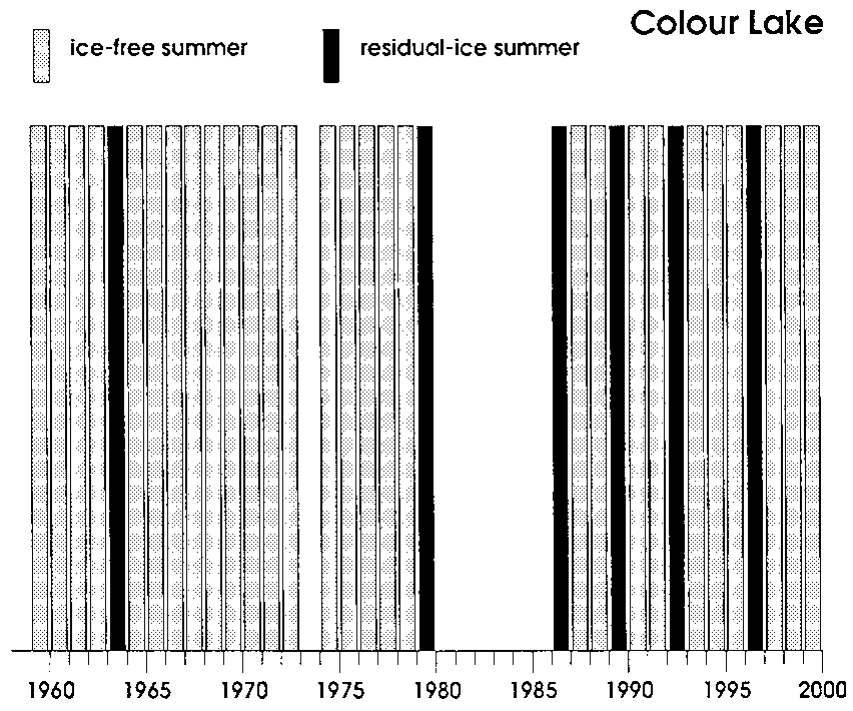

Fig. 3. The ice-off record for Colour Lake, Expedition Fiord, Axel Heiberg Island, 1959-99 The water column remains relatively warm following summers in which ice persists. This reduces the chances of a second successive summer ice cover. The increase in frequency of perennial ice covers is interesting (Doran and others, 1996; Ecclestone and others, in press).

The geobotanical studies of Beschel (e.g. Beschel, 1963a) might better be described as geo-glacio-botanical studies. His early efforts to elucidate the glacial history of land in the vicinity of Axel Heiberg glaciers, and palynological work such as Hegg (1963) continue to be used as work on these matters progresses (e.g. Cogley and Adams, in press).

Many of the topics and themes presented in the two Preliminary reports (B. Müller, 1961; Müller and others, 1963) were developed into full-blown expedition reports and journal papers.

But Fritz's greatest legacy lies in his own work on the glaciers and in the work of others whom he encouraged to work on them. From the very first time he saw these glaciers, he wanted to know everything about them. If he had one overriding interest, it was in climate-glacier relations at high latitudes. He published papers on and speculated about these relationships throughout his career. He would have delighted in this conference on Verification of Cryospheric Models. To understand climate-glacier relationships, he had to gain an understanding of the glaciers and their environment (on short- and long-term bases) and of the internal nature and behaviour of the glaciers.

It always seemed to me that he wanted a three-dimensional fix on each glacier, to know what went on inside, under, beside and on top of it. That is why we dug and drilled so many holes in them, to measure spatial and vertical variations of ablation, accumulation, temperature, crystal size and shape and flow rates. He was fascinated by moulins and the internal and external drainage, plumbing, of the glaciers. To get a similar three-dimensional view of the regional climate, he pressed for simultaneous measurements of basic weather elements at a variety of elevations and locations. This work developed into the mesoclimate studies of Ohmura (e.g. Ohmura and Müller, 1978; Ohmura, 1981, 1982a, b) and Fritz's early efforts with automated weather stations (e.g. Müller, 1967, 1969). When I returned to Axel Heiberg Island in 1983, the solar-powered base camp Ott weather station was still operating, but the tape had 
run out. That tape and others must be in Zürich somewhere. To my knowledge, the first full-year set of weather observations to be published was obtained in 1992-93 from a station still operating at Colour Lake (Doran and others, 1996).

In his initial grand design, Fritz envisaged a sample of small, "medium", and large glaciers to provide a range of climate-glacier response times. His "small" was Baby Glacier $\left(0.613 \mathrm{~km}^{2}\right)$, "medium" White Glacier $\left(38.7 \mathrm{~km}^{2}\right)$ and "large" Thompson Glacier $\left(230.31 \mathrm{~km}^{2}\right)$ with the ice cap from which it issued. He toyed with Crusoe Glacier $\left(43.52 \mathrm{~km}^{2}\right)$ as an extra "medium" glacier because, like Thompson, it appeared to be advancing while White and Baby appeared to be retreating. He also did some work on Iceberg Glacier, the only glacier on Axel Heiberg which reaches the sea. In time, detailed work on Crusoe, Iceberg, Thompson (except for the push moraine) and ice cap fell away. However, work on the last two, as well as on White and Baby, was important in another of Fritz's lasting contributions, his share of the interpretation of equilibrium-accumulation-zone processes, notably the roles of "superimposed ice" in polar-latitude glaciers (e.g. Müller, 1962; cf. Paterson, 1994, fig. 2.1, p. 10).

Over time, work on Baby Glacier also declined. Plans for englacial studies, micrometeorological work and discharge measurements, etc., were gradually shelved. However, mass-balance measurements, including the useful work of Alean and Müller (1977), were more or less maintained. With hindsight, this glacier has proved to be a useful, economical index for regional mass balance, in part because its vertical extent is comparable to that of the "equilibrium zone" (Adams and others, 1998). More detailed knowledge of the glacier would have enhanced the worth of the massbalance record of this rapid-response glacier.

Although mass-balance and movement work on Thompson Glacier were quite limited, its push moraine continues to attract attention. This was one of the features which attracted Fritz's attention to this region in the first place. This type of moraine is an important cold-glacier phenomenon. Early work, following from articles in the Preliminary reports, included Kälin (1971). Wayne Pollard of McGill has continued the push-moraine work (e.g. Moisan, 1991; Moisan and Pollard, 1992, 1995). The terminuses of both Thompson (see below) and Crusoe Glaciers are still advancing.

This brings us to White Glacier which is, as I have said, one of the most studied glaciers in polar regions. The first englacial-temperature drilling of 1959 was followed by many more near-surface holes for temperature and crystallographic analysis. Observations of the passage of water into moulins, and thence from the glacier, and measurements of short-term glacier velocity led Fritz to suspect that this glacier was not frozen at its base, as had been assumed (see Iken, 1974). This train of thought culminated in the massive deep-drilling program of 1974-81 (Blatter, 1987).

The drills probably reached the "bottom" of the glacier in a number of places, confirming and extending basic depth and volume information gained from early seismic and gravity work (e.g. Becker, 1963; Redpath, 1965). Equipped with sensors, these holes, in a well-mapped, well-studied glacier, provided the data for the fine work of Blatter (1987) and Blatter and Hutter (1991) (see also Adams, 1992) on the polythermal structure of polar glaciers. Through them, Fritz's desire for a three-dimensional understanding of the glacier was partly realized. In my view, this work is a major part of Fritz's legacy to glaciology.

The datum for mass-balance work on White Glacier is
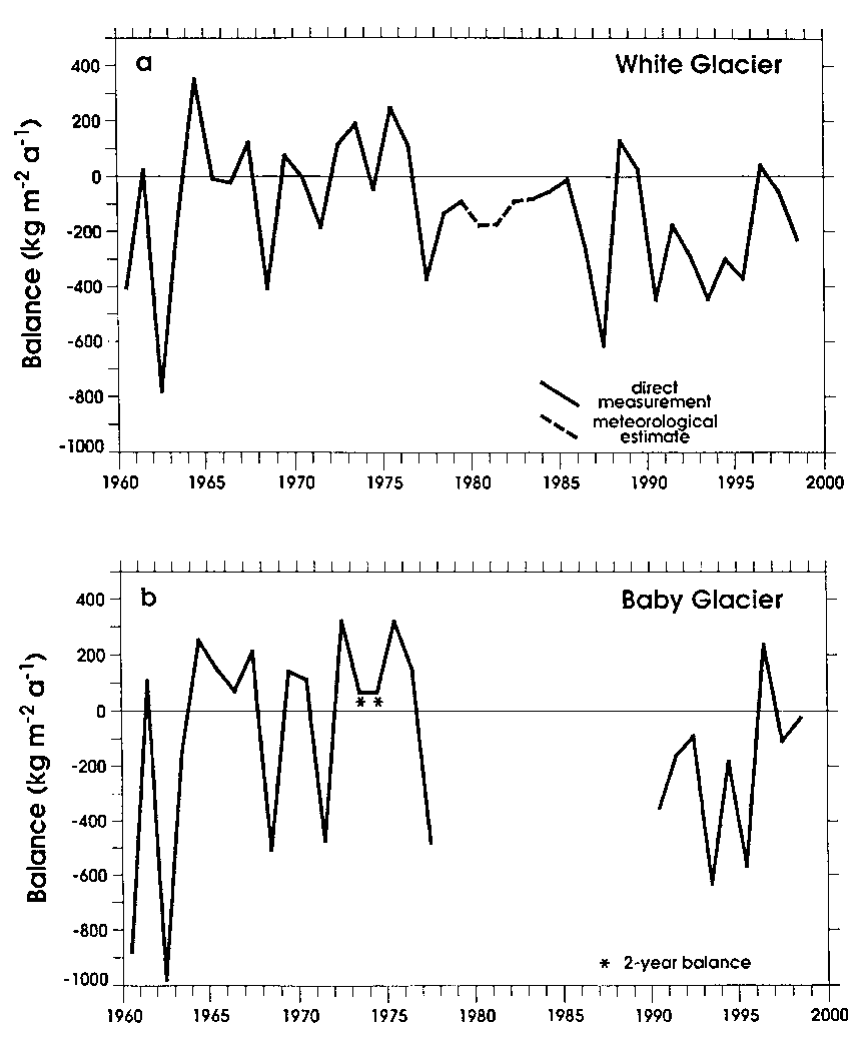

Fig. 4. (a) Mass balance, White Glacier, 1959-98. This series shows a net loss of about $-100 \mathrm{~mm} \mathrm{a}^{-1}$ but without a statistically significant trend. The pattern is not one of steady loss. The net losses of a couple of high-ablation years are similar in magnitude to the net gains of all positive balance years. Occasional but normal extreme years are important in climate-glacier relations, hence the importance of complete, long-term, massbalance records (Cogley and others, 1995, 1996, 1997; Adams and others, 1998). (b) Mass balance, Baby Glacier, 1959-98.

This less complete record also shows a net loss without a trend. There is a good correlation between this series and that of White Glacier (Cogley and others, 1995; Adams and others, 1998).

August 1959, when measurements were initiated near the terminuses and in the equilibrium zone. With some interruptions, measurements have been made every year since (see Cogley and others, 1995, 1996; Cogley and Adams, 1998). In 1960 and 1961, there were hundreds of ablation and accumulation stakes in this one glacier in a valiant effort to capture spatial variations of glacier inputs and losses. One of the contributions of the intensive measurements of those early years was a sense of accumulation-ablation processes on the glacier which helped in interpreting the mass balance for years when there were very few measurement sites. In retrospect, annual measurements from a relatively few well-located stakes would have been a better investment from a purely mass-balance point of view. However, the detail provided by intensive measurements in the equilibrium zone in 1960-62 also contributed to Fritz's work on accumulation-ablation zonation, mentioned above.

Figure 4 shows the mass-balance record for White Glacier from 1959 to the present. Current interest in global warming, with models which suggest a predominance of warming in polar regions, enhances the value of an extended mass-balance record from a glacier which is located at close to $80^{\circ} \mathrm{N}$. An effort has been made recently to tie this work into the behaviour of glaciers around the world (Cogley and Adams, 1998). This is another of Fritz's lasting con- 


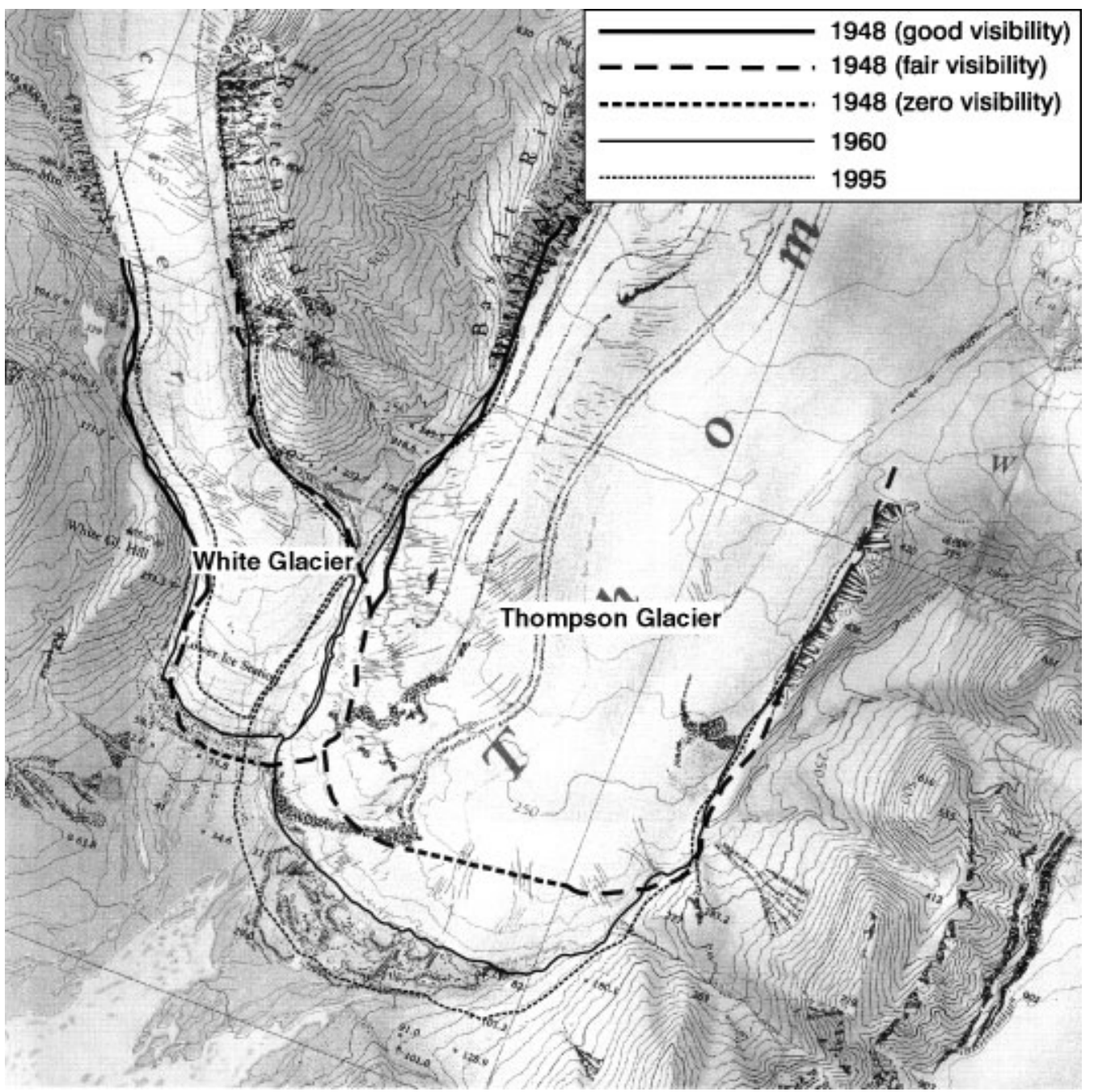

Fig. 5. Terminuses of White and Thompson Glaciers, 1948, 1960 and 1995. Thompson Glacier has been decelerating throughout the period of record and may be approaching a stillstand. White Glacier has retreated during the same time, with a period of nearstillstand in the 1970s. Effects of the interaction of the two terminuses are apparent, for example in the change of shape of White Glacier. This last is a good example of a non-climate control of glacier behaviour (Cogley and Adams, in press).

tributions. Among other things, this recent research benefited from Fritz's work on the World Glacier Inventory (e.g. Müller, 1977; see also Haeberli and others, 1989).

Fritz was very interested in the terminuses of his glaciers. He initiated programs of measurement of their locations and shapes. Early results of this work appear in the Preliminary reports and elsewhere. The maps referred to above were designed to capture the glaciers as they were in air photos of 1959 and in the specially flown photos of 1960 (Haumann, 1963b). Maps at 1:5000 were produced of the White and Thompson terminuses with a great deal of detail both on and off the ice, including the locations of some of Fritz's survey points.

Recently, we relocated Unites States Air Force trimetrogon photos of Expedition Fiord from 1948. Using the 1959 map positions as datum, we were able to reconstruct White and Thompson terminus positions for 1948 and for succeeding years up to the present day. A remarkable amount of aerial photograph and other imagery is available for this region because of the existence of the base houses and the maps. Figure 5 captures another of Fritz's special contributions. In the period of record, Thompson Glacier has continued to advance, but at a generally decreasing rate, while White Glacier has retreated at a generally increasing rate. An interesting feature is the interaction of the two glacier tongues over the years. It looks as though Thompson Glacier will eventually "capture" White Glacier (Cogley and Adams, in press).

Until recently, satellite coverage of Axel Heiberg Island was sporadic, but new satellites provide regular coverage. This, with modern computer techniques, will make it possible to track spatial aspects of high-Arctic glaciers without the enormous expenditure of time and energy that went into the glacier inventory of Ommanney (1969). The opportunities for tracking changes on ice bodies in the region of Fritz Müller's 1:50 000 map are particularly promising. The existence of long mass-balance records in the region enriches the value of such spatial analyses as an indication of glacier response to changes in climate.

\section{CONGLUDING REMARKS}

There is a bibliography of Fritz Müller's publications in Adams and Ommanney (1981). Extensive film coverage of research in Expedition Fiord can be found in the Crawley Collection (National Archives of Canada, Visual and Sound Archives, 344 Wellington Street, Ottawa, Ontario K1A 0N3, Canada; fax 613995 6575; e-mail reference@archives.ca; internet www.archives.ca). Much of this footage was shot by the late F. R. (Budge) Crawley who later received an Oscar 
for the film The man who skied down Everest. In the archives of the Institute of Geography, ETH, are Fritz's fieldbooks, photographs, automated weather station tapes, weather and survey data, and other records. I would suggest that someone with a glaciological background, comfortable in English and German, should be encouraged to document these records and ideally synthesize them in some way. Perhaps the IGS might consider setting up a little group to define this task and fund a fellowship so that it could be accomplished. I would be glad to assist, and so would others who have worked on Axel Heiberg Island. Whether this is done or not, I urge that eventually all records of Fritz Müller's work in Canada be placed in one of the repositories listed in Cogley and Adams (in press).

\section{ACKNOWLEDGEMENTS}

I am most grateful for the assistance of the following: the Hon. J. Stewart and the Hon. R. Nault, Ministers of Indian and Northern Affairs, Canada, the Polar Continental Shelf Project, Natural Resources Canada (for years of support), $\mathrm{H}$. Blatter, C. Brunger, H. Burton, G. Cogley, M. Ecclestone, M. English, D. Feeley, S. Gardiner, Doug Hall and Lorraine Thompson (Industry Canada), T. Moore, A. Ohmura, S. Ommanney, W. Pollard, T. Prowse and L. Taylor. The Institute of Geography, ETH, supported research on Axel Heiberg Island before and after Fritz Müller's death. All those who have worked in Expedition Fiord, Axel Heiberg Island, are grateful to McGill University for continuing to maintain Fritz Müller's station. Special credit goes to K. Hare in the early days and today to T. Moore and in particular W. Pollard, whose research in the region is ongoing and very productive.

We are all grateful to the people of Nunavut, the new Territory in which Axel Heiberg Island now lies. We wish them well in their foundation year and the future.

\section{REFERENCES}

Adams, W. P. 1992. Review: Effect of Climate on the Cryosphere, Climatic Conditions and the Polythermal Structure of Glaciers by H. Blatter. Catena, 19(6), 579-580.

Adams, W. P. 1998. Education and research in Canada's north. In Snellman, O. and R. Langlais, eds. Learning to be circumpolar. Rovaniemi, University of Lapland. Circumpolar Universities Association, 41-56. (Publications of the University of the Arctic, Process No. 5.)

Adams, W. P. and C. S. L. Ommanney. 1981. Obituary. Fritz Müller 19261980. Arctic, 34(2), 195-198.

Adams, W. P., P.T. Doran, M. Ecclestone, C. M. Kingsbury and C. J. Allan. 1989. A rare second year - lake ice cover in the Canadian high Arctic. Arctic, 42(4), 299-306.

Adams, W. P., J. G. Cogley, M. A. Ecclestone and M. N. Demuth. 1998. A small glacier as an index of regional mass balance: Baby Glacier, Axel Heiberg Island, 1959-1992. Geogr. Ann., 80A(1), 37-50.

Alean, J. and F. Müller. 1977. Zum Massenhaushalt des Baby Glacier, Axel Heiberg Island, kanadische Hocharktis. Geogr. Helv., 32(4), 203-208.

Allan, C., S. Schiff, D. Pierson, M. English, M. Ecclestone and W. P. Adams. 1987. Colour Lake, Axel Heiberg Island, N.W.T., a naturally acid, high Arctic, lake - data report. In Adams, W. P., ed. Field research on Axel Heiberg Island, N.W.T., Canada: bibliographies and data reports with appendices of data from the McGill Subarctic Research Station, Schefferville, P.Q. Montréal, Que., McGill University. Centre for Northern Studies and Research, 67-189. (McGill Subarctic Research Paper 41; Axel Heiberg Island Research Report. Miscellaneous Papers 2.)

Andersen, D. T., W. H. Pollard, C. P. McKay and C. Omelon. 1998. Perennial springs in the Canadian high Arctic analogs of past Martian liquid water habitats. [Abstract.] EOS, 79(45), Fall Meeting Supplement, F59.

Becker, A. 1963. On the determination of glacial depth. (Ph.D. thesis, McGill University.)

Beschel, R. E. 1963a. Geobotanical studies on Axel Heiberg Island in 1962. In Müller, F. and 18 others, eds. Facobsen-McGill Arctic Research Expedition
1959-1962; preliminary report 1961-1962. Montréal, Que., McGill University, 199-215. (Axel Heiberg Island Research Reports.)

Beschel, R. E. 1963b. Sulphur springs at Gypsum Hill. In Müller, F. and 18 others, eds. Facobsen-McGill Arctic Research Expedition 1959-1962; preliminary report 1961-1962. Montréal, Que., McGill University, 183-187. (Axel Heiberg Island Research Reports.)

Blachut, T. J. 1963. Photogrammetric and cartographic results of the Axel Heiberg Expedition. Can. Surv., 17(2), 79-80.

Blachut, T. J. and F. Müller. 1966. Some fundamental considerations on glacier mapping. Can. 7. Earth Sci., 3(6), 747-759.

Blatter, H. 1987. On the thermal regime of an Arctic valley glacier: a study of White Glacier, Axel Heiberg Island, N.W.T., Canada. 7. Glaciol., 33 (114), 200-211.

Blatter, H. and K. Hutter. 1991. Polythermal conditions in Arctic glaciers. $\mathcal{F}$. Glaciol., 37(126), 261-269.

Caflisch, T. 1970. Rythmites in the sediments of an Arctic glacial lake, Colour Lake, Axel Heiberg Island, N.W.T. (M.Sc. thesis, McGill University.)

Caflisch, T. 1972. Limnological investigations on Colour and Phantom Lakes. In Müller, F. and 6 others, eds. International Geographical Union, Field Tour Ea 2: Arctic Archipelago I, 22nd International Geographical Congress. Montréal, Que., McGill University, 49-56. (Axel Heiberg Island Research Reports. Miscellaneous Papers.)

Cogley, J. G. and W. P. Adams. 1998. Mass balance of glaciers other than the ice sheets. F. Glaciol., 44(147), 315-325.

Cogley, J. G. and W. P. Adams. In press. Photographic resources for monitoring glacier fluctuations on Axel Heiberg Island. Arctic.

Cogley, J. G., W. P. Adams, M. A. Ecclestone, F. Jung-Rothenhäusler and C. S. L. Ommanney. 1995. Mass balance of Axel Heiberg Island glaciers, 19601991: a reassessment and discussion. Saskatoon, Sask., Environment Canada. National Hydrology Research Institute. (NHRI Science Report 6.)

Cogley, J. G., W. P. Adams, M. A. Ecclestone, F. Jung-Rothenhäusler and C. S. L. Ommanney. 1996. Mass balance of White Glacier, Axel Heiberg Island, N.W.T., Canada, 1960-1991. F. Glaciol., 42(142), 548-563.

Doran, P.T. 1993. Sedimentology of Colour Lake, a nonglacial high Arctic lake, Axel Heiberg Island, N.W.T., Canada. Arct. Alp. Res., 25(4), 353-367.

Doran, P.T., C. P. McKay, W. P. Adams, M. C. English, R. A. Wharton, Jr and M. A. Meyer. 1996. Climate forcing and thermal feedback of residual lake-ice covers in the high Arctic. Limnol. Oceanogr., 41 (5), 839-848.

Doran, P.T., W. P. Adams and M. A. Ecclestone. 1999. Arctic and Antarctic lakes, contrast or continuum? In Lewkowicz, A., ed. Poles apart: a study in contrasts. Ottawa, Ont., University of Ottawa Press, 46-54.

Ecclestone, M. A., J. G. Cogley and W. P. Adams. In press. Ice-related data series from Axel Heiberg Island, Nunavut Territory, Canada. Proc. Eastern Snow Conf.

English, M. and 8 others. 1991. Seasonal changes in the hydrochemistry of land drainage: Colour Lake catchment, Axel Heiberg Island, N.W.T. In Prowse, T. D. and C.S. L. Ommanney, eds. Northern Hydrology: Selected Perspectives. Saskatoon, Sask., Environment Canada. National Hydrology Research Institute, 75-88. ( NHRI Symposium 6.)

Fishback, L. 1995. Seasonal active layer development in the high Arctic, Colour Lake, Axel Heiberg Island, N.W.T. (M.Sc. thesis, University of Waterloo.)

Fricker, P. E. 1963. Geology of the Expedition area, western central Axel Heiberg Island, Canadian Arctic Archipelago. Montréal, Que., McGill University. (Jacobsen-McGill Arctic Research Expedition 1959-1962. Axel Heiberg Island Research Reports. Geology 1.)

Gilbert, R. 1990. Sedimentation in Expedition Fiord, Axel Heiberg Island, Northwest Territories. Géogr. Phys. Quat., 44(1), 71-76.

Gilbert, R., A. E. Aitken and D. S. Lemmen. 1993. The glacimarine sedimentary environment of Expedition Fiord, Canadian high Arctic. Mar. Geol., $110(3 / 4), 257-273$

Haeberli, W., H. Bösch, K. Scherler, G. Østrem and C. C. Wallén, eds. 1989. World glacier inventory: status 1988. Wallingford, Oxon, IAHS Press; Nairobi, GEMS-UNEP; Paris, UNESCO.

Haumann, D. 1963a. Notes on the photogrammetric work. In Müller, F. and 18 others, eds. Facobsen-McGill Arctic Research Expedition 1959-1962; preliminary report 1961-1962. Montréal, Que., McGill University, 237. (Axel Heiberg Island Research Reports.)

Haumann, D. 1963b. Surveying glaciers on Axel Heiberg Island. Can. Surv., $17(2), 81-93$.

Hegg, O. 1963. Palynological studies of a peat deposit in front of the Thompson Glacier. In Müller, F. and 18 others, eds. Facobsen-McGill Arctic Research Expedition 1959-1962; preliminary report 1961-1962. Montréal, Que., McGill University, 217-219. (Axel Heiberg Island Research Reports.)

Iken, A. 1974. Velocity fluctuations of an Arctic valley glacier; a study of the White Glacier, Axel Heiberg Island, Canadian Arctic Archipelago. Montréal, Que., McGill University. (Axel Heiberg Island Research Reports. Glaciology 5.)

Kälin, M. 1971. The active push moraine of the Thompson Glacier, Axel Heiberg Island, Canadian Arctic Archipelago, Canada. Montréal, Que., McGill University. (Axel Heiberg Island Research Reports. Glaciology 4.) 
Maag, H. 1969. Ice-dammed lakes and marginal glacial drainage on Axel Heibers Island, Canadian Arctic Archipelago. Montréal, Que., McGill University. (Axel Heiberg Island Research Reports.)

Maag, H. 1972. Ice-dammed lakes on Axel Heiberg Island, with special reference to the geomorphological effect of the outflowing lake water. In Müller, F. and 6 others, eds. International Geographical Union, Field Tour Ea 2, Arctic Archipelago I, 22nd International Geographical Congress. Montréal, Que., McGill University, 39-48. (Axel Heiberg Island Research Reports. Miscellaneous Papers.)

Moisan, Y. 1991. Recent geomorphic changes in the snout and proglacial zone of the White and Thompson Glaciers, Axel Heiberg Island, Northwest Territories. (M.Sc. thesis, McGill University.)

Moisan, Y. and W. H. Pollard. 1992. Changes at the snout and proglacial zone of the White-Thompson Glacier complex, Axel Heiberg Island, Northwest Territories. Musk-Ox 39, 1-8.

Moisan, Y. and W. Pollard. 1995. Processus d'édification de la structure de poussée du glacier Thompson, île Axel Heiberg, Territoires du Nord-Ouest. Can. Geogr., 39(1), 58-68.

Müller, B. S., ed. 1961. Jacobsen-McGill Arctic Research Expedition to Axel Heiberg Island, Queen Elizabeth Islands: preliminary report of 1959-1960. Montréal, Que., McGill University.

Müller, F. 1962. Zonation in the accumulation area of the glaciers of Axel Heiberg Island, N.W.T., Canada. 7. Glaciol., 4(33), 302-311.

Müller, F. 1963a. Depth sounding projects. In Müller, F. and 18 others, eds. Jacobsen-McGill Arctic Research Expedition 1959-1962; preliminary report 1961-1962. Montréal, Que., McGill University, 103-108. (Axel Heiberg Island Research Reports.)

Müller, F. 1963b. Surveying of glacier movement and mass changes. In Müller, F. and 18 others, eds. Facobsen-McGill Arctic Research Expedition 1959-1962; preliminary report 1961-1962. Montréal, Que., McGill University, 65-80. (Axel Heiberg Island Research Reports.)

Müller, F. 1967. Automatic weather stations for glacier-climate relationship studies. International Association of Scientific Hydrology Vol. VI (General Assembly of Bern 1967- Abstracts of Papers), 75.

Müller, F. 1969a. Automatic climatological recording stations in remote areas. In Instrumentation and Observation Techniques, 14-15 May 1969, Victoria, B.C. Ottawa, Ont., National Research Council of Canada, 205-217. (Canadian Hydrology Symposium 7.)

Müller, F. 1969b. Was the Good Friday Bay glacier on Axel Heiberg Island surging? Can. 7. Earth Sci., 6(4), 891-894.

Müller, F., comp. 1977. Fluctuations of glaciers 1970-1975 (Vol. III). Paris, International Commission on Snow and Ice of the International Association of Hydrological Sciences/UNESCO.

Müller, F. 1981. The living Arctic. Agincourt, Ont., Methuen Publications.

Müller, F. and 18 others. 1963. Facobsen-McGill Arctic Research Expedition 1959 1962; preliminary report 1961-1962 and map supplement. Montréal, Que., McGill University. (Axel Heiberg Island Research Reports.)

Ohmura, A. 1981. Climate and energy balance on Arctic tundra, Axel Heiberg Island, Canadian Arctic Archipelago, spring and summer 1969, 1970 and 1972. (Ph.D. thesis, Eidgenössische Technische Hochschule, Zürich. Geographisches Institut. Dissertation 6587.)
Ohmura, A. 1982a. Climate and energy balance on the Arctic tundra. 7 . Climatol., 2(1), 65-84.

Ohmura, A. 1982b. Evaporation from the surface of the Arctic tundra on Axel Heiberg Island. Water Resour. Res., 18(2), 291-300.

Ohmura, A. and F. Müller. 1978. Aspects of mesoclimatic distribution of air temperature and precipitation over high Arctic tundra, Axel Heiberg Island, N.W.T., Canada. Polar Geogr., 2(4), 270-284.

Omelon, C. 1999. A geochemical investigation of perennial spring activity and associated mineral precipitates at Expedition Fiord, Axel Heiberg Island, Canadian High Arctic. (M.Sc. thesis, McGill University.)

Ommanney, C. S. L. 1969. A study in glacier inventory: the ice masses of Axel Heiberg Island, Canadian Arctic Archipelago. Montréal, Que., McGill University. (Axel Heiberg Island Research Reports. Glaciology 3.)

Ommanney, C. S. L. 1987a. Axel Heiberg Island bibliography. In Adams, P. ed. Field research on Axel Heiberg Island, N.W.T., Canada: bibliographies and data reports with appendices of data from the McGill Subarctic Research Station, Schefferville, P.Q. Montréal, Que., McGill University. Centre for Northern Studies and Research, 5-55. (McGill Subarctic Research Paper 41; Axel Heiberg Island Research Reports. Miscellaneous Papers 2.)

Ommanney, C. S. L. 1987b. Axel Heiberg Island visitations. In Adams, P., ed. Field research on Axel Heiberg Island, N.W.T., Canada: bibliographies and data reports with appendices of data from the McGill Subarctic Research Station, Schefferville, P.Q. Montréal, Que., McGill University. Centre for Northern Studies and Research, 56-66. (McGill Subarctic Research Paper 41; Axel Heiberg Island Research Reports. Miscellaneous Papers 2.)

Paterson, W. S. B. 1994. The physics of glaciers. Third edition. Oxford, etc., Elsevier.

Pollard, W. H. 1991a. Canadian landform examples - 21. Seasonal frost mounds. Can. Geogr., 35(2), 214-218.

Pollard, W. H. 1991b. A high arctic occurrence of seasonal frost mounds. In Prowse, T. D. and C. S. L. Ommanney, eds. Northern Hydrology: Selected Perspectives. Saskatoon, Sask., Environment Canada. National Hydrology Research Institute, 263-275. (NHRI Symposium 6.)

Pollard, W. H. and R. O. van Everdingen. 1992. Formation of seasonal ice bodies. In Dixon, J. C. and A. D. Abrahams, eds. Periglacial geomorphology. Chichester, etc., John Wiley and Sons, 281-304.

Pollard, W., C. Omelon, D. Anderson and C. Mckay. 1998. Geomorphic and hydrologic characteristics of perennial springs on Axel Heiberg Island, N.W.T. Université Laval. Centre d'Études Nordiques. Collection Nordicana 57, 909-914.

Pollard, W., C. Omelon, D. Anderson and C. Mckay. 1999. Perennial spring occurrence in the Expedition Fiord area, Axel Heiberg Island, Canadian High Arctic. Can. 7. Earth Sci., 36(1), 105-120.

Redpath, B. B. 1965. Seismic investigation of glaciers on Axel Heiberg Island, Canadian Arctic Archipelago. Montréal, Que., McGill University. (Jacobsen-McGill Arctic Research Expedition 1959-1962. Axel Heiberg Island Research Reports. Geophysics 1.)

Schiff, S., M. English, M. Ecclestone, R. Elgood, M. Hinton and L. Pezzutto. 1991. Constraints on the origin of acidity in Colour Lake, Axel Heiberg Island $\left(79^{\circ} 25^{\prime}\right.$ N). In Prowse, T. D. and C. S. L. Ommanney, eds. Northern Hydrology: Selected Perspectives. Saskatoon, Sask., Environment Canada. National Hydrology Research Institute, 303-318. (NHRI Symposium 6.) 